\title{
MEDICINAL PLANTS FOR DIABETES MELLITUS: A REVIEW
}

\author{
DIPALI P SHELKE*, VIJAYENDRA SWAMY SM
}

Department of Pharmacology, Channabasweshwar College of Pharmacy (Degree), Latur, MS, India. Email: deep.shelke11@gmail.com Received: 17 January 2021, Revised and Accepted: 05 March 2021

\begin{abstract}
Diabetes mellitus is one of the major health problems in the world, the incidence and associated mortality are increasing. Fourth leading causes of death in the most advanced countries and there, in other emerging and recently industrialized nations, still controlled the epidemic. Inadequate control of blood sugar has significant consequences for well-being. Ayurveda and other Indian writing referenced the utilized of plants in the treatment of different diseases. Medicinal plant with antidiabetic potential has been recent area of research. The efficiency of these medicinal plants may regulate the diabetic metabolic abnormalities. This work would help researchers to choose potential herbal for diabetic treatment.
\end{abstract}

Keywords: Diabetes mellitus, Ayurveda, Medicinal plants, Hypoglycemic.

(C) 2021 The Authors. Published by Innovare Academic Sciences Pvt Ltd. This is an open access article under the CC BY license (http://creativecommons.org/ licenses/by/4.0/) DOI: http://dx.doi.org/10.22159/ajpcr.2021v14i4.40825. Journal homepage: https://innovareacademics.in/journals/index.php/ajpcr

\section{INTRODUCTION}

Diabetes mellitus is an evolving metabolic disease that affects about 143 million people [1] and is estimated to exceed 366 million people in the world by 2030 [2]. Diabetes mellitus is attributed to an irregular absorption of carbohydrates coupled with reduced blood volume of insulin. Diabetes mellitus metabolic disease caused by insulin secretions deficiency. It causes long-term damage in multiple organ systems, deterioration, and failure. Diabetes can contribute to heart failure, renal disease, vascular and neurological complications, and rising death rates. Anti-diabetic herbal therapy may now be commercially developed as a modern drug, although it is accepted that it has medicinal properties in the conventional medicine systems.

Diabetes of type 2 typically develops in obese people and is related to elevated blood pressure and dyslipidemia. The therapy thus aims at reducing the resistance to insulin and promoting insulin secretion. Type 1 Diabetes results in a lack of secretion of insulin to the muscles and the adipose tissue, resulting in poor levels of glucose uptake [3]. Natural medicine (herbal medicine) is used for diabetes care in developed nations, where patients are affected by the expense of conventional medicine [4].

Diabetes and its secondary effects prove to be a significant medical concern through incorporation of hypoglycemic agents in natural and synthetic sources. Many Indian plants have proved useful for controlling diabetes effectively. One of the main benefits of medicinal plants is that they are available conveniently and with relatively low side effects. Plants have always been an example source of medications, many of which are now available directly or indirectly.

The ethnobotanical knowledge has a possible antidiabetic potential of approximately 800 plants [5]. Several plants have shown antidiabetic behavior in their assessment using experimental techniques currently available [6]. This review article lists several medicinal plants with antidiabetic activity and clarifies their action mechanisms including Alangium lamarckii, Albizia odoratissima, Acanthopanax senticosus, Acorus calamus, Berberis vulgaris, Butea monosperma, Bryophyllum pinnatum, Cocos nucifera, Canarium schweinfurthi, Costus speciosus, Centaurium erythrea, Diospyros peregrine, Dillenia indica, Dolichandrone falcata, Eugenia jambolana, Fructus coini, Grewia asiatica, Gymnema sylvestre, Heinsia crinata, Helicteres isora L., Hypericum perforatum L., Irvingia gabonensis, Juglans regia L, Lawsonia inermis, Lithocarpus polystachyus, Momordica charantia, Murraya koenigii L., Myristica fragrans, Nelumbo nucifera, Nyctanthes arbor-tristis L., Olea europaea L., Ocimum sanctum, Opuntia streptacantha, Pandanus odorus, Persea americana Mill., Piper betle L, Psidium guajava, Raphanus sativus, Ricinus communis, Salacia reticulata W., Senna auriculata, Strychnus potatorum L, Terminalia chebula, Tinospora cordifolia, Triticum aestivum, Urtica ardens, Vitis vinifera, Withania somnifera (L.), Xanthium strumarium, Zizyphus sativa Gaertn, and Zygophyllum geslini Coss.

\section{ANTIDIABETIC EFFECT OF FOLKLORE MEDICINAL PLANTS}

\section{A. lamarckii}

Antidiabetic effect of alcoholic extract of A. lamarckii. Alcoholic leaves extract 250 and $500 \mathrm{mg} / \mathrm{kg}$ b.w. was used for these studies. A. lamarckii have significant antidiabetic activity in STZ nicotinamide-induced diabetic rat [7].

\section{B. vulgaris}

Hypoglycaemic effect of $B$. vulgaris L. in streptozotocin-induced diabetic rats $B$. vulgaris is a traditional medicinal plant which belongs to family Berberidaceae. The results indicated that water extract and saponins show significant hypoglycemic effect. The serum cholesterol and serum triglycerides levels were significantly increased [8-11].

\section{C. erythrea}

A single dose of STZ $(65 \mathrm{mg} / \mathrm{kg}$ ) was given intraperitoneally to induce diabetes. By tissue malondialdehyde, oxidative stress was measured. Antioxidant pancreatic enzymes such as superoxide dismutase (SOD), catalase (CAT), and glutathione peroxidase (GPx) are predicted. A substantial decrease in pancreatic tissue TBARS levels has been documented in rats treated with diabetes compared to normal animals. Activity levels of antioxidant resistance enzymes for the pancreas, viz. In the diabetic animals treated, SOD, CAT GPx, and GST were substantially increased. The antioxidant effect of the extract of $C$. erythrea aqueous leaf [12-17]

\section{E. jambolana}

In Ayurveda, an ancient system of Indian medicine, E. jambolana, popularly known as Jamun or Indian blackberry, is suggested for use in DM. In accordance with its anti-diabetic effect claimed in conventional medicine, E. jambolana has been documented in both experimental models and clinical trials to have hypoglycemic effects [18-20]. 
G. sylvestre

The effect was reflected in the activity of gluconeogenetic enzymes and reversal of pathological changes in the liver initiated during the hyperglycemic phase. Oral feeding of powdered leaves of $G$. sylvestre (500 mg/kg body weight) for 10 days significantly prevented IV beryllium nitrate-induced hyperglycaemic in rats and normalized it in 4 days in comparison to 10 days in untreated rats [21-23].

\section{H. crinata}

Alloxan-induced diabetic rat hypoglycaemic effect of $H$. crinata. It is a common medicinal plant belongs to Rubiaceae family. The result shows that by decreasing blood glucose and promoting peripheral glucose use, methanol extract and flavonoids, hydroxy-anthraquinones, saponins, steroids, tannins, and glycoside exhibit substantial hypoglycemic behavior [24]

\section{L. inermis}

A common plant in Asia, L. inermis Linn (Lythraceae), commonly referred to as mehndi, has been widely used as a remedy for diabetes in traditional medicine. A research was thus initiated to evaluate the effect of $L$. inermis leaves extract on the level of blood glucose in diabetic mice induced by alloxan. The result showed that feeding $0.8 \mathrm{gm}$ per $\mathrm{kg}$ of leaf extract body weight lowered the glucose concentration from $194 \mathrm{mg}$ per dilution to normal after day 14 [25-29].

\section{M. charantia}

In different animal models, extracts from fruit pulp, seeds, leaves, and whole plants were shown to have a hypoglycemic effect. Polypeptide $\mathrm{p}$, isolated from fruit, seeds, and tissue of M. charantia. In subcutaneous administration to langurs and humans showed significant hypoglycaemic effect. Ethanolic extracts of M. charantia $(200 \mathrm{mg} / \mathrm{kg})$ exhibited anti-hyperglycemic and hypoglycemic effects in rats with normal and STZ diabetes [30,31].

\section{M. koenigii}

In alloxan-induced diabetic rats $(200,300$, and $400 \mathrm{mg} / \mathrm{kg})$, the aqueous extract of $M$. koenigii leaf significantly decreased blood glucose levels and was shown to have a beneficial effect on the metabolism of

Table 1: Medicinal plants having antidiabetic activity

\begin{tabular}{|c|c|c|c|c|c|}
\hline S. No & Plant Name & Family & Part used & Type of extract & Activity \\
\hline 1 & Alangium lamarckii & Alangiaceae & Leaves & Alcoholic & Antidiabetic activity \\
\hline 2. & Albizia odoratissima & Mimosaceae & Bark & Menthol & Antidiabetic activity \\
\hline 3 & Acanthopanax senticosus & Araliaceae & Whole plant & Aqueous & Antidiabetic activity \\
\hline 4. & Acorus calamus & Acoraceae & Rhizome & Methanol & Antidiabetic activity \\
\hline 5. & Berberis vulgaris & Berberidaceae & Root & Aqueous & Hypoglycaemic \\
\hline 6 & Butea monosperma & Fabaceae & Fruit & Aqueous & Antidiabetic effect \\
\hline 7 & Bryophyllum pinnatum & Crassulaceae & Leaf & Alcoholic & Antidiabetic effect \\
\hline 8 & Cocos nucifera & Arecaceae & Leaf & Hydro-methanol & Antihyperglycemic effect \\
\hline 9 & Canarium schweinfurthi & Burseraceae & Stem bark & Methanolic & Antidiabetic effect \\
\hline 10 & Costus speciosus & Costaceae & Rhizome & Hexane & Antidiabetic effect \\
\hline 11 & Centaurium erythrea & Gentianaceae & Leaf & Aqueous & Antidiabetic activity \\
\hline 12 & Diospyros peregrine & Ebenaceae & Fruit & Aqueous & Antidiabetic activity \\
\hline 13 & Dillenia indica & Dilleniaceae & Leaves & Methanolic & Antidiabetic \\
\hline 14 & Dolichandrone falcata & Bignoniaceae & Leaves & Aqueous & Antidiabetic Potential \\
\hline 15 & Eugenia Jambolana & Asteraceae & seed & Ethanol & Hypoglycemic activity \\
\hline 16 & Fructus coini & Cornaceae & Leaves, Seeds & chloroform & Hypoglycemic activity \\
\hline 17 & Grewia asiatica & Malvaceae & Fruit, Leaves & Ethanol & Antihyperglycemic activity \\
\hline 19 & Heinsia crinata & Rubiaceae & Root & Methanol, hexane & Hypoglycemic activity \\
\hline 20 & Helicteres isora L. & Malvaceae & Fruit & Aqueous & Anti-diabetic activity \\
\hline 21 & Hypericum perforatum L. & Hypericaceae & Leaf & Ethyl acetate & Hypoglycemic activity \\
\hline 22 & Irvingia gabonensis & Irvingiaceae & Seeds & Aqueous & Anti-diabetic activity \\
\hline 23 & Juglans regia $\mathrm{L}$ & Juglandaceae & Leaf & Methanol & Anti-diabetic activity \\
\hline 24 & Lawsonia inermis & Lythraceae & Leaves & Aqueous & Hypoglycemic activity \\
\hline 25 & Lithocarpus polystachyus & Fagaceae & Leaves & Ethanol \& Aqueous & Hypoglycemic activity \\
\hline 26 & Momordica Charantia & Cucurbitaceae & Whole plant & Ethanolic & anti-hyperglycaemic effect \\
\hline 27 & Murraya koenigii L. & Rutaceae & Leaf & Aqueous & Antidiabetic Activity \\
\hline 27 & Myristica fragrans & Myristicaceae & Seeds & petroleum ether & Hypoglycaemic activity \\
\hline 28 & Nelumbo nucifera & Nymphaeaceae & Rhizomes & Ethanolic & Antidiabetic activity \\
\hline 29 & Nyctanthes arbor-tristis L. & Oleaceae & Root & Methanol & Antidiabetic activity \\
\hline 30 & Olea europaea L. & Oleaceae & Leaf & Alcohol & Antidiabetic activity \\
\hline 31 & Ocimum sanctum & Lamiaceae & Leaves & Ethanolic & Antidiabetic effect \\
\hline 32 & Opuntia streptacantha & Cactaceae & Leaves & Ethanol & Antihyperglycemic effect \\
\hline 33 & Pandanus odorus & Pandanaceae & Root & Aqueous & Antidiabetic effect \\
\hline 34 & Persea americana Mill. & Lauraceae & Seed & Ethanol & Antidiabetic effect \\
\hline 38 & Ricinus communis & Euphorbiaceae & Leaf & Aqueous & Anti-diabetic property \\
\hline 39 & Salacia reticulata $\mathrm{W}$. & Hippocrateaceae & Leaf & Aqueous & Anti-diabetic activity \\
\hline 40 & Senna auriculata & Fabaceae & Flowers & Aqueous & Hypoglycaemic effects \\
\hline 41 & Strychnus potatorum L. & Loganiaceae & Seeds & Aqueous and Ethanol & Anti-diabetic activity \\
\hline 42 & Terminalia chebula & Combretaceae & Fruits & Ethanolic & Anti-diabetic activity \\
\hline 43 & Tinospora cordifolia & Menispermaceae & Roots & Aqueous & Antidiabetic activity \\
\hline 44 & Triticum aestivum & Poaceae & Husk & Ethanolic & Antidiabetic activity \\
\hline 45 & Urtica ardens & Urticaceae & Leaves & Hydro-alcoholic & Antidiabetic activity \\
\hline 46 & Vitis vinifera & Vitaceae & Leaves & Ethanolic & Antidiabetic activity \\
\hline 47 & Withania somnifera (L.) & Solanaceae & Leaf \& Root & Ethanolic & Anti-diabetic activity \\
\hline 48 & Xanthium strumarium & Asteraceae & Stem & Methanolic & Hypoglycemic effect \\
\hline 49 & Zizyphus sativa gaertn & Rhamnaceae & Leaf & Alcohol & Anti-diabetic activity \\
\hline 50 & Zygophyllum geslini Coss & Zygophyllaceae & Aerial parts extract & Aqueous & Anti-diabetic activity \\
\hline
\end{tabular}


carbohydrates. In addition, this plant's ethanol extract in mice increases dexamethasone-induced hyperglycemia and insulin tolerance in part by increasing the disposal of glucose into the skeletal muscle [32].

\section{N. nucifera}

Oral administration of the ethanolic extract of rhizomes of $N$. nucifera significantly reduced the blood sugar level of normal, glucose hyperglycemic, and streptozotocin-induced diabetic rats when compared with control animals. The extract increased glucose tolerance and potentiated the action of exogenously injected insulin in normal rats $[33,34]$

\section{O. europaea L.}

In normal and streptozotocin-induced diabetic rats, the antidiabetic activity of alcohol extract of olive (O. europaea L.) leaves has been investigated. Serum glucose, total cholesterol, triglycerides, urea, uric acid, creatinine, aspartate aminotransferase, and alanine aminotransferase decreased significantly during oral administration of olive leaf extract $(0.1,0.25$ and $0.5 \mathrm{~g} / \mathrm{kg}$ body wt.) for 14 days, while serum insulin increased in diabetic rats but not in regular rats $[35,36]$.

\section{P. betle}

$P$. betle leaves have marked hypoglycemic activity (in fasted normoglycemic rats) and antihyperglycemic activity (in STZ-induced diabetic rats, by enhancing the glucose tolerance test and lowering the blood glucose level). The dose-dependent hypoglycemic effect of $P$. betle extract on fasting normoglycemic rats was up to $4 \mathrm{~h}$ apart from the lowest dose of hot water extract (HWE). In addition, the hypoglycemic ability of HWE and cold ethanol extract was comparable to that of tolbutamide, the sulphonyl urea-type reference hypoglycemic medication [37-41].

\section{R. communis}

In both normal and alloxan diabetic rats, the results of this plant showed a potent reduction of blood glucose activity. It was found that the effective dose of $R$. communis $500 \mathrm{mg} / \mathrm{kg}$ body weight. The administration of this ethanol extract to diabetic rats for 20 days not only substantially decreased the level of blood glucose in diabetic animals to almost normal levels but also raised the level of insulin and improved the lipid profile and body weight of diabetic animals. The design of an effective phytomedicine for diabetes seems to have a promising value, although more detailed pharmacological studies are required to elucidate the exact mechanism of the $R$. communis root extract [42-44].

\section{S. reticulata}

The effects of aqueous extract prepared from the leaves of $S$. reticulata on the absorption of sugars in normal and type 1 diabetic mice were investigated. The simultaneous oral administration of the extract at a dose of $1.0 \mathrm{mg} /$ mouse with maltose or sucrose inhibited the postprandial elevation of the plasma glucose and insulin levels and intestinal alphaglucosidase activities in mice. Hence, the water extract of the leaves of $S$. reticulata could be a beneficial food material for the prevention of diabetes and obesity because of its multiple effects [45-50].

\section{W. somnifera}

W. somnifera is an essential medicinal plant, which is used in conventional medicine to cure various diseases. Flavonoids were determined in the extracts of $W$. somnifera root (WSREt) and leaf (WSLEt). The amounts of total flavonoids found in WSREt and WSLEt were 530 and $520 \mathrm{mg} / 100 \mathrm{~g}$ dry weight, respectively. Hypoglycemic and hypolipidemic effects of WSR Et and WSLEt were also studied in alloxan-induced diabetic rats [51-54].

\section{CONCLUSION}

In this study, we have explored the treatment of diabetes mellitus with folk medicinal plants. Most folk medicinal plants are used in rural areas because of the vast variety of medicinal plants present in these areas. Thus, mellitus therapy with plants appeared highly desirable derived compounds that are accessible and do not need laborious pharmacological synthesis. In this study, an effort has been made to research the antidiabetic medicinal plants which can be useful in developing antidiabetic medicines for health practitioners, scientists, and scholars interested in pharmacology and therapeutics.

\section{ACKNOWLEDGMENT}

We wish to express our sincere acknowledgment to Dr. Vijayendra Swamy S.J., Principal, Channabasweshwar Pharmacy College Latur, Maharashtra, India for their valuable support and encouragement throughout the work.

\section{AUTHOR'S CONTRIBUTION}

DS performed and wrote the manuscript draft and design the concept and finalized the manuscript.

\section{CONFLICT OF INTEREST}

The authors confirm they have no conflict of interest.

\section{AUTHOR'S FUNDING}

No funding provided for research work.

\section{REFERENCES}

1. Mungle A, Bodhankar M, Chandak K. Antidiabetic potential of Dolichandrone falcata leaves in alloxan induced diabetic rats. Int J Res Pharm Biomed Sci 2012:3:319-24.

2. Ahangarpour A, Mohammadian M, Dianat M. Antidiabetic effect of hydroalcholic Urtica dioica leaf extract in male rats with fructoseinduced insulin resistance. Iran J Med Sci 2012;37:181-6.

3. Lehninger AL, Nelson DL. MM Cox. Principle of Biochemistry. New York: Worth Publishers; 2010.

4. Alarcon-Aguilara FJ, Roman-Ramos R, Perez-Gutierrez S, AguilarContreras A, Contreras-Weber CC, Flores-Saenz JL. Study of the antihyperglycemic effect of plants used as antidiabetics. J Ethnopharmacol 1998;61:101-10.

5. Anand KK, Singh B, Grand D, Chandan BK, Gupta VN. Effect of Zizyphus sativa leaves on blood glucose levels in normal and alloxaninduced diabetic rats. J Ethnopharmacol 1989;27:121-7.

6. Arambewela LS, Arawwawala LD, Ratnasooriya WD. Antidiabetic activities of aqueous and ethanolic extracts of Piper betle leaves in rats. J Ethnopharmacol 2005;102:239-45.

7. Arokiyaraj S, Balamurugan R. Antihyperglycemic effect of Hypericum perforatum ethyl acetate extract on streptozotocin-induced diabetic rats. Asian Pac J Trop Biomed 2011;1:386-90.

8. Cakici I, Hurmoglu C. Hypoglycemic effects of Momordica charantia extract in normoglycaemic or cyproheptadin induced hyperglycaemic mice. J Ethnopharmacol 1994;44:117-22.

9. Cetto AA, Wiedenfeld H. Anti-hyperglycemic effect of Opuntia streptacantha Lem. J Ethnopharmacol 2011;133:940-3.

10. Kumar D, Kumar S, Kohli S, Arya R, Gupta J. Antidiabetic activity of methanolic bark extract of Albizia odoratissima Benth. in alloxan induced diabetic albino mice. Asian Pac J Trop Med 2011;4:900-3.

11. Edem DO. Hypoglycemic effects of ethanolic extracts of Persea americana Mill seed (Alligator Pear.) in rats. Eur J Sci Res 2009;33:669-78.

12. Eidi A, Eidi M, Darzi R. Antidiabetic effect of Olea europaea L. in normal and diabetic rats. Phytother Res 2009;23:347-50.

13. Eliza J, Diasy P, Ignacimuthu S, Duraipandiyan V. Antidiabetic and antilipidemic effect of eremanthin from Costus speciosus (Koen.) Sm., in STZ-induced diabetic rats. Chem Biol Interact 2009;182:67-72.

14. Farzaneh V, Carvalho IS. A review of the health benefit potentials of herbal plant infusions and their mechanism of actions. Ind Crops Prod 2015;65:247-58.

15. Grover JK, Vats V, Rathi SS. Antihyperglycemic effect of Eugenia jambolana and Tinospora cordifolia in experimental diabetes and their effects on key metabolic enzyme involved in carbohydrate metabolism. J Ethnopharmacol 2000;73:461-70.

16. Hannan JMA, Marenah L, Ali L, Rokeya B, Flatt PR, Abdel-Wahab YH. Ocimum sanctum leaf extracts stimulate insulin secretion from perfused pancreas, isolated islets and clonal pancreatic ß-cells. J Endocrinol 2006;189:127-36.

17. Hou SZ, Chen SX, Huang S, Jiang DX, Zhou CJ, Chen CQ, et al. The 
hypoglycemic activity of Lithocarpus polystachyus Rehd. leaves in the experimental hyperglycemic rats. J Ethnopharmacol 2011;138:142-9.

18. Huang CS, Yin MC, Chiu LC. Antihyperglycemic and antioxidative potential of Psidium guajava fruit in streptozotocin-induced diabetic rats. Food Chem Toxicol 2011;41:2189-95.

19. Jafri MA, Aslam M, Javed K, Singh S. Effect of Punica granatum Linn (flowers) on blood glucose level in normal and alloxan-induced diabetic rats. J Ethnopharmacol 2000;70:309-14.

20. Jianfang F, Jufang F, Jun Y, Zhang N, Gao B, Fu G, et al. Anti-Diabetic activities of Acanthopanax senticosus polysaccharide (ASP) in combination with metformin. Int J Biol Macromol 2012;50:619-23.

21. Kamtchouing P, Kahpui SM, Djomeni Dzeufiet PD, Tédong L, Asongalem EA, Dimo T. Anti-diabetic activity of methanol/ methylene chloride stem bark extracts of Terminalia superba and Canarium schweinfurthii on streptozotocin-induced diabetic rats. J Ethnopharmacol 2005;104:306-9.

22. Khan IA, Khanum A. Modern and Alternative Medicine for Diabetes. Hyderabad, India: Ukaaz Publication; 2005.

23. Kumar GP, Arunselvan P, Kumar DS, Subramanian P. Anti-diabetic activity of fruits of Terminalia chebula on streptozotocin-induced diabetic rats. J Health Sci 2006;52:283-91.

24. Kumar S, Kumar V, Prakash O. Antidiabetic, hypolipidemic and histopathological analysis of Dillenia indica (L.) leaves extract on alloxan induced diabetic rats. Asian Pac J Trop Med 2011;4:347-52.

25. Macharla SP, Goli V, Sattla SR. Antidiabetic activity of Rephanus sativus $\mathrm{L}$, leaves extracts on alloxan induced diabetic rats. J Chem Pharm Res 2012;4:1519-22.

26. Medjdoub H, Tabti B, Baatouche M, Baou L, Zehhaf S, Azzeddine K. Antihyperglycemic effect of Zygophyllum geslini aqueous extract in streptozotocin-induced diabetic wistar rats. J Life Sci 2012;6:652-6.

27. Meliani N, Amine Dib ME, Allali H, Tabti B. Hypoglycaemic effect of Berberis vulgaris $\mathrm{L}$. in normal and streptozotocin induced diabetic rats. Asian Pac J Trop Biomed 2011;6:468-71.

28. Mentreddy SR, Mohamed AI, Rimando AM. The Alzheimer's Association International Conference; 2005. p. 341-53.

29. Mohan Y, Jesuthankaraj GN, Thangavelu NR. Antidiabetic and antioxidant properties of Triticum aestivum in streptozotocin-induced diabetic rats. Adv Pharmacol Sci 2013;2013:716073.

30. Mukherjee PK, Saha K, Pal M, Saha BP. Effect of Nelumbo nucifera rhizome extract on blood sugar level in rats. J Ethnopharmacol 1997;58:207-13.

31. Narendiran S, Mohanambal E. Study of anti-diabetic and anti-oxidant activities of methanolic extract of Xanthium strumarium (Linn.) stems on diabetic rats. J Pharm Res 2011;4:3728-32.

32. Ojewole JA. Antinociceptive, anti-inflammatory and antidiabetic effects of Bryophyllum pinnatum (Crassulaceae) leaf aqueous extract. J Ethnopharmacol 2005;99:13-9.

33. Ozolua RI, Eriyamremu GE, Okene EO, Ochei U. Hypoglycemic effects of viscous preparation of Irvingia gabonensis (Dikanut) seeds in streptozotocin induced diabetic wistar rats. J Herb Spices Med Plants 2006;12:1-9.

34. Pandey J, Maurya R, Raykhera R, Srivastava MN, Yadav PP, Tamrakar AK. Murraya koenigii (L.) spreng. ameliorates insulin resistance in dexamethasone-treated mice by enhancing peripheral insulin sensitivity. J Sci Food Agric 2014;94:2282-8.

35. Peunqvicha P, Thirawarapan SS, Watanabe H. Hypoglycemic effect of water extract of the root of Pandanus odorus RIDL. Biol Pharm Bull 1996;19:364-6.

36. Ponnusamy S, Ravindran R, Zinjarde S, Bhargava S, Kumar AR.
Evaluation of traditional Indian antidiabetic medicinal plants for human pancreatic amylase inhibitory effect in vitro. Evid Based Complement Alternat Med 2011;2011:515647.

37. Prisilla DH, Balamurugan R, Shah HR. Antidiabetic activity of methanol extract of Acorus calamus in STZ induced diabetic rats. Asian Pac J Trop Biomed 2012;2:S941-6.

38. Kumar R, Pate DK, Prasad SK, Sairam K, Hemalatha S. Antidiabetic activity of alcoholic leaves extract of Alangium lamarckii Thwaites on streptozotocin-nicotinamide induced Type 2 diabetic rats. Asian Pac J Trop Med 2011;4:904-9.

39. Joshi RK, Setzer WN, Veiga VF Jr. Aromatic and medicinal plants with anti-diabetic potential from India: A review. Am J Essent Oils Nat Prod 2015;2:24.

40. Ravi K, Ramachandran B. Effect of Eugenia jambolana seed kernel on antioxidant defense system in streptozotocin induced diabetes in rats. Life Sci 2004;75:2717-31

41. Roman-Ramos R, Flores-Saenz JL, Alarcon-Aguilar FJ. Antihyperglycemic effect of some edible plants. J Ethnopharmacol 1995;48:25-32

42. Saravanan G, Pari L. Hypoglycaemic and antihyperglycaemic effect of Syzygium cumini bark in streptozotocin-induced diabetic rats. J Pharmacol Toxicol 2008;3:1-10.

43. Sefi M, Fetoui H, Lachkar N, Tahraoui A, Lyoussi B, Boudawara T, et al. Centaurium erythrea (Gentianaceae) leaf extract alleviates streptozotocin-induced oxidative stress and $\beta$-cell damage in rat pancreas. J Ethnopharmacol 2011;135:243-50.

44. Sendogdu N, Aslan M. Antidiabetic and antioxidant effects of Vitis vinifera $\mathrm{L}$. leaves in streptozotocin-diabetic rats. Turk J Pharm Sci 2006;3:7-18

45. Sharma V, Marwaha A. Hypoglycemic activity of methanolic extracts of Nyctanthes arbor-tristis Linn. root in alloxan induced diabetic rats. Int J Pharm Pharm Sci 2011;3:210-2.

46. Somani RS, Singhai AK. Hypoglycaemic and antidiabetic activities of seeds of Myristica fragrans in normoglycaemic and alloxan-induced diabetic rats. Asian J Exp Sci 2008;22:95-102.

47. Suman RK, Borde MK. Antidiabetic activity of Gymnema sylvestre leaves extract on streptozocin induced experimental diabetic rats. Indo Am J Pharm Res 2015;5:2054-60.

48. Winarno H. The effect of Inai (Lawsonia inermis) leaves extract on blood glucose level: An experimental study. Res J Pharmacol 2008;2:20-3.

49. Teimori M, Montasser KS. Study of hypoglycemic effect of Juglans regia leaves and its mechanism. J Med Plants 2010;9:57-65.

50. Tshibangu PT, Kapepula PM, Kapinga MJ, Mukuta AT, Kalenda DT, Tchinda AT, et al. Antiplasmodial activity of Heinsia crinita (Rubiaceae) and identification of new iridoids. J Ethnopharmacol 2017;196:261-6.

51. Udayakumar R, Kasthurirengan S, Mariashibu TS, Rajesh M, Anbazhagan VR, Kim SC, et al. Hypoglycaemic and hypolipidaemic effects of Withania somnifera root and leaf extracts on alloxan-induced diabetic rats. Int J Mol Sci 2009;10:2367-82.

52. Vikrant A, Sharma R. A review on fruits having anti-diabetic potential. J Chem Pharm Res 2011;3:204-12.

53. Wani TA, Pandith SA, Rana S, Bhat WW, Dhar N, Razdan S, et al. Promiscuous breeding behaviour in relation to reproductive success in Grewia asiatica L. (Malvaceae). Flora Morphol Distribut Funct Ecol Plants 2015;211:62-71.

54. Yoshino K, Miyauchi Y, Kanetaka T, Takagi Y, Koga K. Anti-diabetic activity of a leaf extract prepared from Salacia reticulata in mice. Biosci Biotechnol Biochem 2009;73:1096-104. 